\title{
Conflict Perception and Emotional Labour in Nursing
}

1 Mirjana Ćavar

2 Olivera Petrak

${ }^{1}$ Clinic for Infectious Diseases „Dr. Fran Mihaljević“”, Zagreb

2 Department of Health Psychology, University of Applied Health Sciences, Zagreb

Article received: 31.10.2017.

Article accepted: 26.02.2018.

Author for correspondence:

Olivera Petrak

University of Applied Health Sciences

Mlinarska cesta 38, Zagreb, Croatia

Phone: + 385914595927

E-mail: olivera.petrak@zvu.hr

DOI: $10.24141 / 2 / 2 / 1 / 2$

Keywords: nurses, conflict, emotional labour

\section{Abstract}

More and more intense way of life and work, global crisis which causes lack of work resources, make it more difficult to provide adequate health care and lead to stress and conflict at different levels of healthcare activities. Healthcare professionals are exposed to emotional labour on a daily basis. Continuous management and regulation of their emotions may exhaust them, make their work harder and increase the occurrence of conflict. On the other hand, it is possible that conflict itself could be the source of stress and negative emotions which require greater emotional labour in order to be concealed or suppressed.

The aim of this research was to examine different features of conflict in the workplace, the level of emotional labour experienced by nurses, and the relationship between the perception of conflict and emotional labour.

The research was carried out anonymously on the convenience sample of 104 female (94.2\%) and male (5.8\%) nurses at the Hospital for Infectious Diseases in Zagreb. The average age of the participants was 36 years, and their average work experience was 15.9 years. For the purpose of the research the Questionnaire on Various Features of Conflict by Stojčić \& Perković, and the Questionnaire on Emotional labour by Näring, Briët \& Brouwers were used.

$76 \%$ of the participants perceive conflict as destructive. Conflict in the workplace is not frequent, and the majority of the participants consider themselves as successful in constructive resolution of conflict. 
Persons with longer work experience enter into conflict more often. Nurses are not exposed to intense emotional labour; workers with secondary education invest greater emotional labour than those with university education. The hierarchical analysis has shown that it is possible to explain $38.4 \%$ of the variance of conflict frequency with sets of predictors (age, education level, different work problems, emotional labour). The most important predictors were age, problematic behavior of colleagues and expressing positive emotions. Emotional labour has a significant, but small part in conflict frequency.

\section{Introduction}

A nurse's job includes teamwork, as well as direct contact with the patient to whom, except for nursing care, they also provide emotional support (1). Since the foundation of the nursing profession is interaction with patients, colleagues and other healthcare and non-healthcare professionals, well-developed communication skills are of great importance and they include recognition and constructive resolution of conflict. Conflicts are an inevitable part of interpersonal relationships, which makes them an inevitable part of the nursing profession as well. The term conflict denotes a situation in which there are opposite occurrences and tendencies, behaviors, emotions and the like (2). Every person has their own notion of the world, their value system and criteria of judging everyday life situations, therefore it is no wonder that, in interaction with others, we come into conflict for many different reasons on a daily basis. Conflict is a social process which consists of many episodes of different intensity and manifestation. It occurs because needs, wishes, goals and ways of their fulfillment are not harmonized, and the actions of one side hinder the other in achieving its goals (3). An attempt to provide an unambiguous definition of conflict is made more difficult by its dynamism, because it may assume qualitatively different shapes and manifestations (4).

In everyday life, conflict is often identified with a confrontation, disrespect, loss or violence. It is considered as a negative, stressful and unpleasant oc- currence, which people tend to avoid because it causes negative emotions such as anger, hatred, rage or fear. The negative consequences of conflict are dissatisfaction and weakening of relationships, work efficacy and communication. However, conflict could be also seen as an opportunity to improve interpersonal relationships. Every change and progress is the result of some sort of conflict, so conflict itself is neither good nor bad. Conflict can be constructive, it can improve the quality of decisions, provoke creativity and innovativeness, stimulate interest and curiosity within a team, become an instrument for reducing tensions and, in the end, enable better adjustment to changes (4). Consequently, it is very important to know how to resolve conflict in a constructive way.

Conflicts are present in all types of organizations, thus they are present in health care institutions as well. Unresolved conflict among healthcare professionals can have bad influence on patient care, so it is necessary to resolve it before it could impact the quality of provided care.

Each conflict has a cause, but the attempt to define the cause in an unambiguous way can have the same obstacles as defining the conflict itself. We can distinguish between the causes of conflict at the level of the organization and on an individual level (5). The most common causes at the level of an organization are changes in the organization (reorganization, dismissals, changes in law), differences between the employees (sex, age, origin or education), differences in strategy issues (health care procedures are regulated in advance but they need to be adapted according to the needs and characteristics of every patient) and limited resources (lack of human resources or materials). Vaguely determined responsibility or a bad reward system can cause conflicts among individuals or work departments, and the same can happen with different aims or expectations - although the general purpose of a healthcare organization is clear, different problems appear in practice because of the discord between effectiveness and high cost of medical procedures. Demanding workload or high professional and ethical standards, which are characteristic for the medical profession, for example irregular and more frequent shifts, result in diminishing professional and personal satisfaction, which can lead to a higher number of conflicts (6). The causes of conflict on the individual level could be different experience of reality, different value system, the sense of being threatened or lack of confidence. 
Conflict is almost always a combination of many causes. Working in an organization, as well as teamwork, presents a challenge for everybody involved because it demands from different people to connect in a harmonious unit which acts as one. Therefore, resolution of conflict becomes a complex process. It is possible to use different strategies in conflict resolution (5): avoidance, giving in, competition, compromise or cooperation. Cooperation includes open and direct confrontation with the conflict and searching for mutually acceptable solution. It is the only strategy which resolves the conflict completely because it does not leave place for unresolved questions which could turn into conflict again.

Along with constructive conflict resolution, the work of nurses demands managing and regulating emotions as well because they have a professional obligation to express feelings which are in accordance with their work, and which are often not the ones they really feel. Every day they find themselves in situations which require expressing compassion, interest, kindness and empathy, and if they don't really experience these emotions, then they have to conceal their own emotions and act, i.e. try to feel the emotions expected from them. In critical situations nurses have to remain focused and neutral. Such emotional labour could be extremely demanding, and although it can momentarily lead to increased efficacy, if it is continuous it causes higher stress and faster burnout, as well as diminished work satisfaction (7). Conflict and emotional labour are mutually related: increased emotional labour exhausts nurses and in that way contributes to harder work conditions, which are then a good foundation for conflict. $A$ reverse situation is possible as well: conflict could be the source of stress and negative emotions which, in working conditions, demand higher emotional labour in order to conceal or suppress those emotions (8). In literature, authors distinguish the following types of emotional labour (9): surface acting - showing emotions which are appropriate to the situation, but without actually feeling them, for example smiling to an unpleasant patient; deep acting - which includes effort of controlling thoughts and feelings to really experience and express the expected emotions; and suppressing or concealing unpleasant emotions, such as dislike towards certain team members or patients, aversion or fear in critical situations. Analyzing the relation between conflict and emotional labour was of secondary interest in the nursing practice, and was not a subject of any research in Croatia. Therefore, the purpose of this research is to examine the relation between perception of conflict and emotional labour among nurses. To achieve this aim what needs to be determined are the characteristics of conflict which nurses experience in their workplace, participants, sources and intensity of conflict and ways of conflict resolution. Another aim is to examine in which measure are the participants exposed to emotional labour in their workplace and the relation between the characteristics of conflict and emotional labour in nursing practice.

\section{Methods}

\section{Participants}

This research was carried out on the convenience pattern of 115 participants who completed an anonymous questionnaire at the Clinic for Infectious Diseases "Dr. Fran Mihaljević" in Zagreb in September 2016. 9 questionnaires were declared invalid due to them having incomplete answers. Among the 104 participants, 98 were female (94.2\%) and 6 male (5.8\%) nurses, which is an expected sex distribution because it matches the general sex distribution in the profession. More than half of the participants graduated from secondary school (61.5\%), $27.9 \%$ had a college degree and $10.6 \%$ had a university degree. The average age of the participants was 36 years (in the range 20-60), and average work experience was 15.9 years (in the range $1-40$ ).

\section{Instruments and procedure}

The research was carried out in written form by means of two questionnaires. The first questionnaire, by Stojčić \& Perković, has 14 closed-ended questions which refer to the presence of different problems in the workplace as potential sources of conflict, frequency, participants and ways of resolving conflict. The participants had to:

a) choose the most accurate definition of conflict among 3 offered answers;

b) estimate the frequency of 16 problematic behavior of colleagues in the workplace (such 
as Lack of patience when working with the patients), and determine in what degree are specified behaviors the cause of them entering into conflict. The exploratory factor analysis was conducted on questions about the frequency of problematic behavior in the work of colleagues and three factors were identified which accounted for $60 \%$ of the total variance, but even after rotation the identified factors could not be interpreted in a meaningful way. As all items were saturated by the first factor, which alone accounted for the $43 \%$ of the variance, we decided to use a single-factor structure and expressed the whole score on this question/subscale. For the question how much the specified behaviors were the cause of them coming into conflict, we got a similar situation, and because all items had moderate to high saturation by the first factor which accounted for over $43 \%$ of the variance, this question/subscale is also treated as a singlefactor structure.

c) estimate the presence of 9 potential problems in the organization of work (such as Personnel shortage). The conducted factor analysis has clearly indicated the existence of two factors which could be interpreted as relationship problems and lack of resources problems. Relationship problems accounted for the 31\% of the variance, and this factor saturated six items, such as lack of reward system. The second factor - lack of resources accounts for the additional $28.8 \%$, and saturates three items: shortage of personnel, shortage of working resources and shortage of space.

d) estimate the frequency of their own conflicts with the superiors, colleagues, subordinates or patients.

e) estimate the way of resolving conflict (immediately or at a later time, directly or hierarchically). For the questions marked b) to e) answers were offered on the scale from 1 never to 5 - always.

f) estimate their own success in constructive resolution of conflict at work, and the answers were offered on the scale from 1 - not successful to 5 - excellent.

The permission to use this questionnaire was granted by the authors and some closed-ended questions were added. The questions referred to when the participants last participated in a conflict, how often conflict happens at work, which strategy they mainly use when they find themselves in a conflict (such as establish cooperation, or avoid discussion), what is the most common source or conflict (for example age or sex differences, conflict personalities), and what conflict influences the most (for example productivity, low self-confidence).

The second questionnaire used was the Questionnaire on Emotional Labour from 2007, by Näring, Briët \& Brouwers (9). It contains 25 closed-ended questions whose answers range from 1 - never to 4 - always. Because this questionnaire was rarely used among the Croatian population, its structure was verified using the confirmatory factor analysis on 3 factors, modeled on the three-factor structure which was obtained using the Croatian sample (10). The following factors were identified: acting (14 items; such as I pretend to be kind at work), expressing positive emotions (8 items; such as I calm down agitated people at work) and applying emotional labour (3 items, such as I try really hard to feel the emotions I need to show to others). After recoding the items 7, 13, 16 and 21, the higher total score on the subscales shows more prominent acting, more positive emotions and higher emotional labour.

In instructions for the participants it was pointed out that completing the questionnaires was voluntary and anonymous, and in order to ensure that, the completed questionnaires were put in a special envelope in every department.

The results were processed by SPSS software program, version 17.0.

\section{Results}

Firstly, we wanted to examine how nurses define conflict. Among the offered answers, as much as 76\% participants defined conflict as a negative situation in which there is a confrontation, insulting, aggression and hostility. 13.5\% participants chose the definition of conflict as an unwanted clashing situation, and only $5.8 \%$ thought that conflict is only a situation in which some people openly express their opin- 
ion, disagreement or frustration. The remaining $4.7 \%$ did not choose any of the offered definitions, and did not provide their own definition either.

The average score for perceiving the frequency of problematic behavior of colleagues is in the lower half of the score scale, which shows relatively rare observation of such behavior in the work of colleagues. The participants stated that they very rarely come into conflict because of the problematic behavior of their colleagues (the arithmetic mean the sum divided by number of statements - equals 2.1 , which is closest to the answer very rarely). On the subscale of problems in relationships with coworkers, the average score is in the middle of the score scale, which shows periodical presence of such problems. Lack of resources is also present in the organization of participants' work activities, and the average answer is somewhere between sometimes and often.

The majority of the participants chose the answer never or very rarely to the question how often and with whom they come into conflict for all offered categories, which shows low conflict frequency. Most often superiors are the cause of conflict, while patients and their relatives and subordinates are groups with whom participants most rarely come into conflict.
For the question When do you solve conflict in the workplace, our participants most often decide to resolve the conflict immediately $-57.7 \%$ of them chose the terms often or always in regard to this answer, while $18.3 \%$ decide to resolve it at a later time. Only $5.7 \%$ of the participants stated that they often or always do not resolve conflicts at all. $68.3 \%$ of the participants claimed that they often or always resolve conflicts directly, while $15.4 \%$ of them prefer to do it hierarchically.

A bit more than half of the participants consider themselves successful in constructive conflict resolution (51\%), $21.2 \%$ consider themselves as very successful, while one person considered herself or himself as excellent. $26.9 \%$ of them thought they are unsuccessful or not successful enough in constructive resolution of conflicts.

For the question when they took part in conflict in the workplace, as much as $50 \%$ of the participants stated that they do not remember, $18.3 \%$ claimed it was in the previous month, while $12.5 \%$ stated the conflict occurred in the previous 6 months. For $10.6 \%$ of the participants it happened in the previous year, while only $8.7 \%$ participants experienced conflict in the previous week.

\begin{tabular}{|c|c|c|c|c|c|c|}
\hline Subscale & M & D & SD & Min & Max & $\begin{array}{l}\text { Theoretical } \\
\text { range }\end{array}$ \\
\hline Problematic behavior of colleagues & 47.73 & 33 & 11.884 & 25 & 75 & $16-80$ \\
\hline $\begin{array}{c}\text { Coming into conflict because of the } \\
\text { problematic behavior }\end{array}$ & 33.55 & 26 & 9.955 & 20 & 70 & $16-80$ \\
\hline Relationship problems & 17.75 & 16 & 4.906 & 6 & 28 & $6-30$ \\
\hline Lack of resources & 10.41 & 9 & 2.657 & 3 & 15 & $3-15$ \\
\hline
\end{tabular}

Table 2. Percentage of answers to the question with whom participants most often come into conflict $(\mathrm{N}=\mathbf{1 0 5})$

\begin{tabular}{|cccccc|}
\hline Answer & Never & Very rarely & Sometimes & Often & Always \\
\hline Superiors & 49.0 & 32.7 & 13.5 & 1.0 & 3.8 \\
\hline Co-workers & 26.0 & 53.8 & 16.3 & 1.9 & 1.9 \\
\hline Subordinates & 46.2 & 46.2 & 6.7 & 0.0 & 1.0 \\
\hline Patients or relatives & 51.0 & 42.3 & 6.7 & 0.0 & 0.0 \\
\hline
\end{tabular}


The majority of the participants (41.3\%) think that conflict in the workplace happens once a month, while $23.1 \%$ or them think that conflict happens only once in 6 months. $18.3 \%$ of the participants consider that conflict in the workplace happens very often. Only $10.6 \%$ of the participants experienced conflict in the workplace only once a year, while the smallest number of the participants $(5.8 \%)$ state that there are almost no conflicts at all. As the cause of conflict, more than half of the participants $(56.7 \%)$ most often see conflict personalities, which implies that the majority of conflicts are personal and that they occur at the individual level, while at the same time, 5.8\% of them think that the cause is age or sex difference. $19.2 \%$ of the participants think the cause of conflict is unclear division of work, and $8.7 \%$ consider the unreliability of co-workers and bad management as the cause.

The great majority of the participants think that conflicts mostly affect productivity in the workplace $(70.2 \%), 14.4 \%$ of them think that they mostly have an effect on low self-confidence, $11.5 \%$ of the participants think that conflicts mostly have an effect on psychosomatic diseases, and one participant thinks that they have an effect on mental diseases.

Table 3 shows the descriptive statistics of the extracted factors from the Questionnaire on Emotional Labour. The average score of the group of statements which are projected on the factor Acting is 25.36, which is a low score which shows that the participants do not tend to act out emotions, while the average score on the subscale Expressing positive emotions shows that they often express such emotions. The score on the subscale Investing emotional effort shows relatively high effort in understanding the patients' problems.

Participants with secondary education invest significantly higher emotional labour, compared with the groups of participants with college or university edu- cation ( $t=2.081 ; d f=102 ; p=0.040)$, and they enter into conflict with fewer people ( $M$ for college and university education -7.58 ; $M$ for secondary education $-6.59) ;(t=2.183 ; d f=102 ; p=0.031)$.

The correlation between the examined constructs was checked, and only the significant correlations will be shown. Participants with longer work experience come into conflict in the workplace more often ( $r=0.278, p=0.004)$, even though the correlations are not significantly high. Furthermore, with regard to the effect of work experience, partial correlations with the control variable of work experience were calculated. The participants who act more in the workplace consider themselves less successful in constructive resolution of conflicts, but here the correlation is low as well $(r=-0.270 ; p=0.006)$. The ones who perceive problematic behavior of colleagues more often, come more often into conflict because of such behavior $(r=0.444 ; p=0.000)$ with a greater number people $(r=0.487 ; p=0.000)$, they more often perceive problems in interpersonal relationships ( $r=0.603 ; p=0.000)$, as well as problems regarding the lack of resources ( $r=0.260 ; p=0.008)$, and in higher degree act out their emotions in the workplace $(r=0.265, p=0.007)$.

Participants who come into conflict in the workplace more often because of the problematic behavior of others, do it with a greater number of people ( $r=$ $0.614 ; p=0.000$ ), notice problems in interpersonal relationships more often $(r=0.380 ; p=0.000)$, and act more $(r=0.281 ; p=0.004)$. Coming into conflict in the workplace more often because of the problematic behavior of others is negatively correlated with expressing positive emotions $(r=-0.248 ; p=$ $0.012)$. Noticing problems in relationships more often is correlated with a higher score on the subscale Lack of resources $(r=0.433 ; p=0.000)$ and with coming into conflict with a greater number of people in the workplace ( $r=0.493 ; p=0.000)$. There is low positive correlation between the level of education of the

Table 3. Descriptive statistics for the factors in the Questionnaire on Emotional Labour (N=104)

\begin{tabular}{|c|c|c|c|c|c|c|}
\hline Factor & M & D & SD & Min & $\operatorname{Max}$ & $\begin{array}{c}\text { Theoretical } \\
\text { range }\end{array}$ \\
\hline Acting & 25.36 & 23 & 5.377 & 14 & 41 & $14-56$ \\
\hline Expressing positive emotions & 25.71 & 28 & 3.026 & 19 & 32 & $8-32$ \\
\hline Investing emotional effort & 6.90 & 6 & 1.983 & 3 & 12 & $3-12$ \\
\hline
\end{tabular}


participants and success in constructive resolution of conflict ( $r o=0.284 ; p=0.004$ ): if the participants are more educated, then they in some degree consider themselves more successful in resolving conflicts at work.

Hierarchical regression analysis was conducted for the criterion of conflict frequency, and it was expressed in the question with whom and how often participants most often come into conflict in the workplace. We wanted to determine if adding a specific predictor, in this case emotional labour, significantly increases the predictive value of the criterion. Variables which correlate moderately with the criterion, as well as among themselves, between 0.28 and 0.6 , were used as predictors

In the first step of the regression equation age and education level of the participants were introduced. According to the corrected estimate (which is in this case a better indicator than $\mathrm{R}^{2}$, because of the greater number of predictors), $10 \%$ of the variance of the criteria was accounted for, and both predictors proved as significant: older participants and those with a higher level of education come more often into conflict. The second step included various difficulties in the workplace: problematic behavior of colleagues, relationship problems and lack of resources. By introducing this group of predictors additional $23.8 \%$ of the variance was accounted for, which represents significant contribution. The important predictors in the second step are problematic behavior of colleagues and relationship problems. Coming more often into conflict is connected with noticing unsuitable or inappropriate behavior of others more often, or it is connected with relationship problems. In the third step the group of predictors of interest were introduced, and they were the aspects of emotional labour which only account for the additional $4.6 \%$ of the variance, among which expressing positive emotions is the only significant predictor. Hierarchical analysis explained a total of $38.4 \%$ of the variance of conflict frequency. The most important predictor is problematic behavior of colleagues, and a bit less significant predictor is expressing positive emotions: there are more conflicts if a person more often notices problematic or inappropriate behavior of colleagues and if they express positive emotions at work as less as possible.

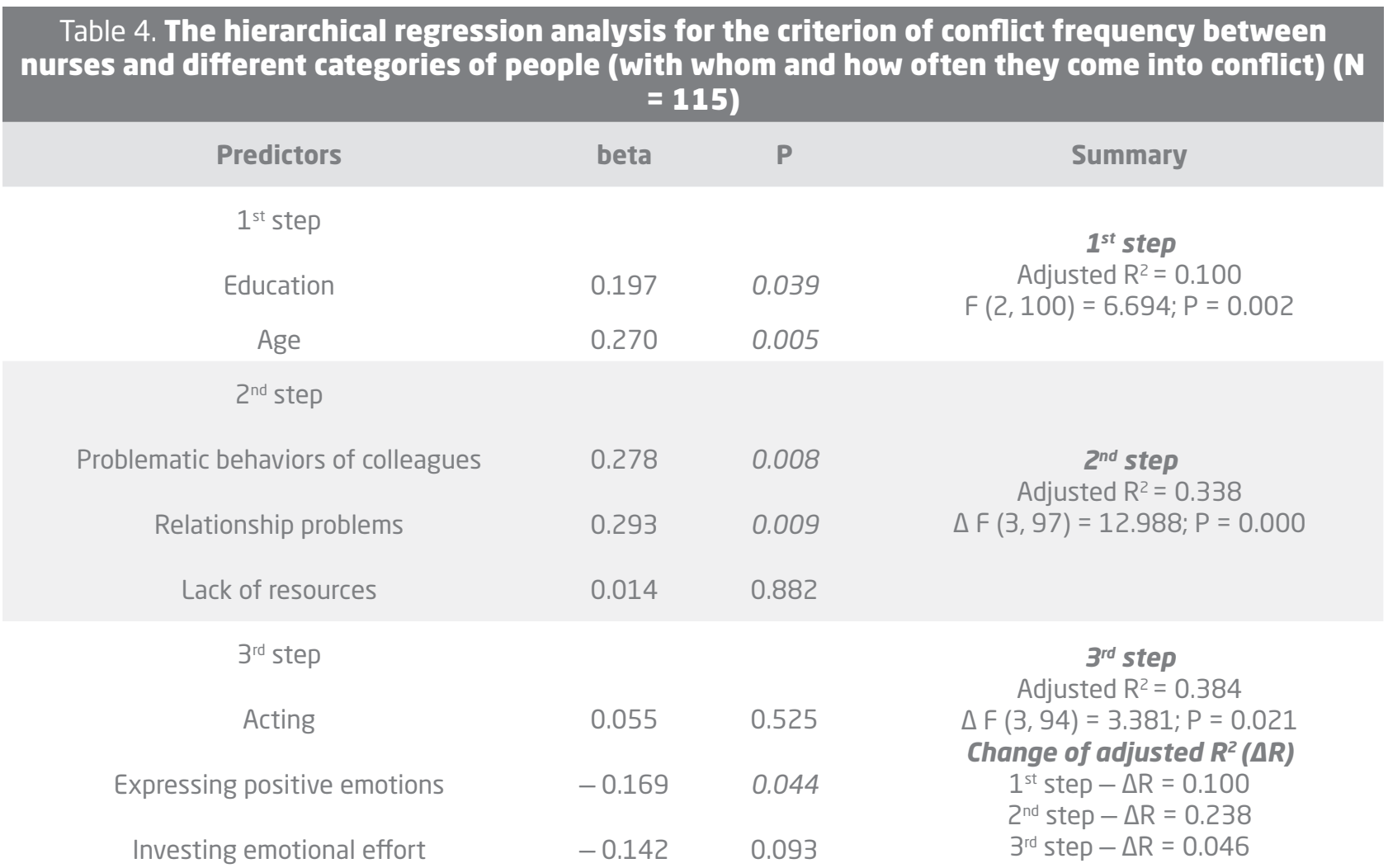




\section{Discussion}

We were interested in how nurses experience conflict in the workplace, the causes, frequency and some other characteristics of conflict, and whether their perception of conflict is in some way connected with the aspects of emotional labour they are exposed to at work. More than three quarters of the participants think that conflict is a very destructive experience with which they connect aggression, hostility, confrontations and insults, while only $5.8 \%$ of the participants see the constructive side of conflict - expressing one's opinions, disapproval or frustration openly. These results show the basic lack of knowledge of the nature of conflict, which is not a good foundation for its successful resolution. Experiencing conflict in such a way causes chronic relationship problems, and this is harmful not only for the organization itself, but for providing quality nursing care as well. For comparison, in a research conducted in Bjelovar General Hospital, 54\% of nurses evaluated conflict as extremely negative, which is a high percentage as well (4). Since conflict can increase the quality of decision making and enable better adjustment to change, it is not favourable that great majority of the participants evaluate conflict as a very negative experience. Therefore, a continuous education of nursing staff about conflict and its potential is needed. The assumption is that nurses with a higher level of education will provide more of the correct answers, but that was not proven. The problem probably stems from the insufficient education of undergraduate students or the atmosphere in individual organizations. Conflict is still a topic avoided in society, although it is present in some form on a daily basis. For example, in some graduate specialist nursing studies, the course Conflict Management is an elective course, and taking into consideration the importance of the topic, it would be good to include it as an obligatory course, which could contribute to changing the perception of conflict as something which is necessarily negative or unwanted.

Most of the participants have chosen answers never or rarely for the question with whom and how often they mainly come into conflict. On average, $15 \%$ of the participants sometimes come into conflict with their superiors or colleagues. Therefore it is not unusual that they avoid conflict because most of them consider conflict as an extremely negative experience. People who cause conflict are not very popular, which is a consequence of an anti-conflict culture in which we grew up (11).

Majority of the participants often or always resolve conflict immediately and in a direct manner, and more rarely hierarchically or at a later time. This means that conflicts are solved "face to face", without involving other colleagues at work. Direct and prompt resolution of conflict is usually more constructive than hierarchical or postponed approach. Hierarchical conflict resolution is adequate in situations of long lasting personal conflicts which were not resolved directly, or when the main cause of conflict is the organization of work. Therefore, it is not surprising that majority of the participants consider themselves successful in constructive conflict resolution, because they manage to solve them on their own, without the interference of their superiors. A confirmation that conflict is not frequent in the workplace can be found in the information that as much as half of the participants do not remember when they were involved in a conflict at work, and $30 \%$ of them think that conflicts occur once a month or once every six months. The great majority of participants thinks that conflicts most often harm productivity in the workplace (70.2\%), which is an argument in favor of the presumption that conflicts should be resolved constructively, because otherwise, they directly impact the quality of the provided health care.

A little more than half of the participants see conflict personality as the most often cause of conflict, and only a smaller part think that the cause can be found in age or sex differences. Therefore it is possible to conclude that the main cause of conflict can mostly be found in character traits. For comparison, in hospitals in Rijeka and Zadar the causes of conflict in the workplace are in the highest percentage of non-professional character (72\%), i.e., to be more precise, due to differences in character traits (12). Professional causes are marginalized in comparison to personal differences. It should not be surprising that the most often causes of conflict are interpersonal relationships, since nursing always encompasses teamwork, which is exceptionally demanding; every member has their role and responsibility, which opens up a possibility for potential escalation of conflict between them. Many situations can be a possible source of conflict: maltreatment or violence towards coworkers, marginalization of those who are 
different, different perception of work among colleagues of different age, work experience, education level or cultural values, the fact that trainees and/or new workers do not have the support of the experienced nurses or organization system of the hospital, etc. (13). Therefore, it is somewhat surprising that the participants think that sociodemographic differences very rarely become the source of conflict, and at the same time, we experience emphasis of such differences and polarization in our society. At the same time, it has been shown that participants with college or university degree come into conflict with more people than the participants with secondary education; so there is the difference which is linked to certain sociodemographic characteristics. Of course, these results should be taken with caution, because the research was conducted in only one health institution, which could have its own specific organizational characteristics.

The most often cause of conflict at the level of an organization is unclear division of work, followed by unreliability of coworkers and bad management. However, character traits remain the main cause of conflict. In almost every organization there are people with difficult personality, who see a great problem in a small difficulty, who are demanding or tend to constantly complain. Such individuals tend to also come into conflict more often. This may also be pointed at by the finding that those who notice inappropriate or problematic behavior of others at work come into conflict more often, with more people and more often notice problems in interpersonal relationships because of the organization of work. This could have something to do with perfectionism as a character trait when a person is very demanding at work and experiences frustration when people around them do not meet their high standards, especially when this interferes with workplace obligations of that person.

Regarding the emotional labour to which participants are exposed, it cannot be stated that it is very significant: expressing positive emotions occurs more often than acting or investing emotional effort: employees of the Clinic only sometimes act out emotions, and often feel or try to feel positive emotions. The results are in accordance with the research by Petrak and associates, which showed that nurses only sometimes turn to acting out or concealing emotions, and a bit more often show positive emotions sincerely, and often behave in accordance with workplace demands (10). The nurses with second- ary education invest significantly more emotional labour than nurses with college or university degree. The reason for this could be education in the field of health psychology and communication skills, which is a part of the curriculum at higher levels of education.

Participants with college or university degrees come into conflict with a greater number of people, which is as expected, because college or university include a broader scope of education (such as learning about emotional intelligence, conflict and assertiveness as way of conflict resolution, etc.) which gives higher self-confidence and active approach to problems which participants encounter at work. Participants with a higher level of education cooperate with more people of different professions and education levels, manage various groups of employees, negotiate, manage and motivate their subordinates.

Participants with more work experience come into conflict with a greater number of people in the workplace. The results are as expected, because the experience gives them greater self-confidence, security and greater freedom, because of which they will not avoid conflicts when they appear. This finding could be interpreted by the cumulation of the number of people with whom a participant came into conflict, which happens during greater period of time.

Participants who act more at work, as well as those with secondary education, see themselves as less successful in constructive resolution of conflicts, which is what was expected. Namely, constructive resolution of conflicts demands a certain level of knowledge and experience and developed communication skills. The conditions which are necessary for constructive conflict resolution are trust among the participants in the conflict, revealing who the participants are, accurate perception of the conflict, cooperation among the participants in the process of resolving conflict and their sincere communication $(14,15)$.

Participants who more often come into conflict at work because of the problematic behavior of colleagues, more often notice problems in the organization of work regarding interpersonal relationships and come into conflict with a greater number of people. The results of an Australian research (16) indicate that nurses come into conflict most often during shift handover, just because of work overload during their shift. After a hard day or night at work, it is very difficult to hide negative emotions which appear af- 
ter physical, psychological and emotional overload. Those who more often state shortcomings in the organization of work, come into conflict with more people in the workplace. It is very hard to work in a place with any type of poor organization. Insufficient number of nurses in a shift frustrates individuals and the whole team, because there is always fear that something will not be done in time or that a patient will be left without care, and lack of equipment and unclear task delegation make the situation even worse (17).

Hierarchical regression analysis with the criterion of conflict frequency, which was expressed by the question with whom they most often come into conflict at work, was conducted in three steps and it explains over $30 \%$ of the criterion variance. In the first step, age and education level have solid and significant contribution to explaining the criterion. As it was mentioned earlier, it was expected that the frequency of conflict increases with age because of the accumulation of such experiences through the years, and people with a higher level of education are more conscious of their rights and more self-confident as well, and they have higher skills of standing up for what they believe in, so they are more ready to enter into conflict. In the second step, by controlling age and education level, perception of problematic colleague behavior and relationship problems appeared as significant predictors. Their contribution to the explanation of the variance of conflict frequency is significantly higher than with previous predictors (over 23\%). This indicates that relationships are primarily the foundation for conflict, but we cannot be completely sure about the background of this finding. Namely, it is possible that a health professional has very high criteria (which can be of decisive importance in health care), and justifiably requires from their colleagues to adhere to those criteria, but the colleagues do not agree with that. However, the situation could be different as well, for example, there is a person with conflict personality who notices and points to the smallest mistakes made by others, and with such behavior causes conflict more often, because they exaggerate in their criticism. It is known that some types of personalities, for example rigid, inflexible people, are more prone to conflict than others (18). Although emotional labour in the third step significantly and independently contributes to the explanation of the variance of conflict frequency, this contribution is still limited, and the only significant predictor in this group is expressing positive emotions which is in negative relationship with the criterion. This analysis does not explain causal relationship between the variables, so it is possible that a person who feels better and expresses this enters into conflict less. On the other hand, it is possible that positive emotions are the consequence of the pleasant work atmosphere with fewer number of conflicts. The contribution of emotional labour in the explanation of conflict frequency is significant, but still weak.

Suggestions for further research are oriented towards the verification of the specified constructs on other, larger samples, and the improvement of the Questionnaire on Various Features of Conflict, which participants mainly found to be too comprehensive, and some questions were unclear to them, especially those related to the problematic behavior of colleagues and frequency of entering into conflict. Therefore, the recommendation for future users is to shorten the questionnaire and make the questions more simple. It is also necessary to find a more precise quantitative measure of conflict frequency than the one used in this research (such as: with whom and how often do you come in conflict), and introduce some personality dimensions which could additionally explain the relationship between the cause of conflict and its frequency.

\section{Conclusion}

Conflict is a significant part of our everyday life and we react to it in the way we learned through life. However, through formal education we become aware of the skills needed to manage and solve it. It seems that in Croatia we still do not hear enough about this "undesirable" topic. Namely, the great majority of the participants in this research see conflict as an exclusively destructive occurrence. Conflict defined in this way is not frequent in the work of nurses. Participants stated that they enter into conflict very rarely and in most cases with their superiors. More educated and older participants enter into conflict more often. Interpersonal relationships turned out to be the most important feature of conflict. Regardless of the effort, difficulties and lack of resources which 
nurses encounter, it seems that quality relationships are of decisive importance for creating a working atmosphere without incidents, and could in some degree compensate for hard working conditions.

Nurses in the institution in which the research was conducted are not very exposed to emotional labour. Only sometimes they turn to acting out emotions, the emotional labour is not significant, and they often feel or try to feel positive emotions. A lower education level is connected with greater emotional labour. Hierarchical regression analysis has shown that conflict is more frequent as the participants are older, as they notice more problematic behavior of colleagues or when they show positive emotions to a lesser degree. Emotional labour plays a significant, but small part in conflict frequency.

\section{References}

1. Pukljak Iričanin Z, Babić J, Perković L. Uloga emocionaIne inteligencije u radu medicinskih sestara. In: Županić M, Turuk V, editors. Zbornik radova 12. Međunarodne konferencije medicinskih sestara i tehničara „Izazovi suvremenog sestrinstva". Zagreb: Zdravstveno veleučilište; 2012. 147-151.

2. Hrvatska enciklopedija. Available on http://www.enciklopedija.hr/natuknica.aspx?id=32777 Downloaded: 5 March 2016.

3. Despot Lučanin J, Havelka M. Rješavanje sukoba. In: Lučanin D, Despot Lučanin J, editors. Komunikacijske vještine u zdravstvu. Zagreb: Zdravstveno veleučilište and Naklada Slap; 2010. 163-173.

4. Stojčić Ž, Perković L, Stašević I, Stojčić N, Ropac D. Ispitivanje odnosa percepcije sukoba i asertivnosti kod medicinskih sestara. Acta Medica Croatica. 2014; 68: 259-271.

5. Rijavec M, Miljković D. Kako rješavati konflikte? Zagreb: VERN; 2002.
6. Šimunić $A$, Gregov Lj. Conflict between work and family roles and satisfaction among nurses in different shift system in Croatia: A questionnaire survey. Arh Hig Rada Toksikol. 2012; 63:189-197.

7. Lesjak R, Sindik J. Emocionalna inteligencija medicinskih sestara. Sestrinski glasnik. 2013; 18(3): 174-181.

8. Cribbs A. Emotional labour and conflict in schools: teacher perceptions of the emotional display rules necessary for negative teacher - student interaction. 2015: University of Pittsburg.

9. Näring G, Briët M, Brouwers A. Validation of the Dutch Questionnaire on Emotional Labour (D-QEL) in Nurses and Teachers. In Richter P, Peiro JM, Schaufeli WB, editors. Psychosocial resources in human services work. München: Hampp Publishers; 2007. 135-145.

10. Petrak 0, Bartolac A, Pavić J. Emocionalni rad i sagorijevanje medicinskih sestara. 20. godišnja konferencija hrvatskih psihologa. Dubrovnik: Zdravstveno veleučilište Zagreb; 2015. 7-10.

11. Rijavec M. Uspješan menadžer - svakodnevne metode upravljanja. Zagreb: M.E.P. Consult; 1995.

12. Ljubičić M, Lakić M. Sukobi na radnom mjestu. Available on: www.hkms.hr/data/1243232923_106_maIa_SUKOBI\%20NA\%20RADNOM\%20MJESTU\%20 \%Marija\%20Ljubi\%C4\%8Di\%C4\%87,\%20Mirjana\%20 Laki\%C4\%87.doc. Downloaded: 7 January 2017.

13. Practice guideline: Conflict Prevention and Management. College of nurses of Ontario. 2009. Available on http://www.cno.org/globalassets/docs/prac/47004_ conflict_prev.pdf Downloaded: 20 January 2017.

14. Kalauz S. Organizacija i upravljanje u području zdravstvene njege. Zagreb: Medicinska naklada; 2015.

15. Antolović J, Turkalj Podmanicki M. Načela i smjernice za organizacije u kulturi. Ekonomski Vjesnik. 2010; 13(1): 152-167.

16. Happell B and collabourators. Nurses and stress: recognizing causes and seeking solution. Journal of Nursing Management. 2013; 21(4): 638-647.

17. Dušak M. Procjena emocionalne kompetencije i razine stresa kod medicinskih sestara u jedinici intenzivnog liječenja. HČJZ. 2012; 31(7-8): 72-83.

18. Eddy B. Who are high conflict people? 2012. http:// www.highconflictinstitute.com/who-are-high-conflict-people. Downloaded: 20 October 2017. 


\section{PERCEPCIJA SUKOBA I EMOCIONALNI NAPOR U SESTRINSTVU}

\section{Sažetak}

Sve intenzivniji način života i rada te globalna kriza koja za sobom povlači nedostatak sredstava za rad otežavaju pružanje adekvatne zdravstvene skrbi i dovode do stresa i sukoba na različitim razinama zdravstvene djelatnosti. Zdravstveni djelatnici svakodnevno su izloženi emocionalnom naporu - upravljanju i reguliranju svojih emocija, što ih može iscrpljivati, otežavati rad i pospješiti pojavu sukoba. No moguće je i da su sukobi izvor stresa i negativnih emocija koje zahtijevaju veći emocionalni napor za njihovo prikrivanje ili potiskivanje.

Cilj istraživanja bio je ispitati različita obilježja sukoba na radnom mjestu, razinu emocionalnog napora koje doživljavaju medicinske sestre te odnos percepcije sukoba i emocionalnog napora.

Istraživanje je provedeno anonimno na prigodnom uzorku od 104 medicinskih sestara $(94,2 \%)$ i tehničara $(5,8 \%)$ u Klinici za infektivne bolesti u Zagrebu. Prosječna je dob sudionika 36 godina, a radnog staža 15,9 godina. Korišten je upitnik o različitim obilježjima sukoba autora Stojčić i Perković te Upitnik emocionalnog napora autora Näring, Briët i Brouwers.

76 \% sudionika percipira sukob kao destruktivnu pojavu. Sukobi na radnom mjestu nisu učestali, a većina sudionika smatra se uspješnima u konstruktivnom rješavanju sukoba. Više se sukobljavaju oni s dužim radnim stažem. Medicinske sestre nisu izložene intenzivnom emocionalnom naporu; djelatnici sa srednjom stručnom spremom ulažu veći emocionalni trud u odnosu na one s višim obrazovanjem. Hijerarhijska analiza pokazala je da se setovima prediktora (dob i stručna sprema, različiti problemi u radu, emocionalni napor) može objasniti 38,4 \% varijance učestalosti sukoba, pri čemu su značajni prediktori dob, problematična ponašanja suradnika i izražavanje pozitivnih emocija. Emocionalni napor ima značajan, ali skroman udio u učestalosti sukoba.

Ključne riječi: medicinske sestre, sukob, emocionalni napor, emocionalni rad 